\title{
Impact of humic acid on the degradation of levofloxacin by aqueous permanganate: Kinetics and mechanism
}

\author{
Ke Xu ${ }^{\text {a }}$, Weiwei Ben ${ }^{a}$, Wencui Ling ${ }^{\mathrm{b}}$, Yu Zhang a , Jiuhui Qu ${ }^{\mathrm{a}}$, Zhimin Qiang ${ }^{\mathrm{a}, *}$ \\ ${ }^{a}$ Key Laboratory of Drinking Water Science and Technology, Research Center for Eco-Environmental Sciences, University of Chinese Academy of Sciences, \\ Chinese Academy of Sciences, 18 Shuang-qing Road, Beijing 100085, China \\ ${ }^{\mathrm{b}}$ Beijing Municipal Research Institute of Environmental Protection, 59 Beiyingfang Middle Street, Beijing 100037, China
}

\section{A R T I C L E I N F O}

\section{Article history:}

Received 28 February 2017

Received in revised form 8 June 2017

Accepted 13 June 2017

Available online 14 June 2017

\section{Keywords:}

Permanganate

Levofloxacin

Humic acid

Hydroxyl radical

Water treatment

\begin{abstract}
A B S T R A C T
Levofloxacin (LF) is a frequently detected fluoroquinolone in surface water, and permanganate $\left(\mathrm{MnO}_{4}^{-}\right)$is a commonly used oxidant in drinking water treatment. This study investigated the impact of humic acid (HA) on $\mathrm{LF}$ degradation by aqueous $\mathrm{MnO}_{4}^{-}$from both kinetic and mechanistic aspects. In the absence of $\mathrm{HA}$, the second-order rate constant $(k)$ of $\mathrm{LF}$ degradation by $\mathrm{MnO}_{4}^{-}$was determined to be $3.9 \mathrm{M}^{-1} \mathrm{~s}^{-1}$ at $\mathrm{pH} 7.5$, which increased with decreasing $\mathrm{pH}$. In the presence of $\mathrm{HA}$, the pseudo-first-order rate constant $\left(k_{\text {obs }}\right)$ of LF degradation at pH 7.5 was significantly increased by 3.8 - and 2.8 -fold at $[\mathrm{HA}]_{0}:\left[\mathrm{KMnO}_{4}\right]_{\mathrm{o}}$ (mass ratio) $=0.5$ and 1 , respectively. Secondary oxidant scavenging and electron paramagnetic resonance tests indicated that $\mathrm{HA}$ could form a complex with $\mathrm{Mn}(\mathrm{III})$, a strongly oxidative intermediate produced in the reaction of $\mathrm{MnO}_{4}^{-}$with $\mathrm{HA}$, to induce the successive formation of superoxide radicals $\left(\mathrm{O}_{2}{ }^{--}\right)$and hydroxyl radicals $(\cdot \mathrm{OH})$. The resulting $\cdot \mathrm{OH}$ primarily contributed to the accelerated LF degradation, and the complex [HA-Mn(III)] could account for the rest of acceleration. The degradation of $\mathrm{LF}$ and its byproducts during $\mathrm{MnO}_{4}^{-}$oxidation was mainly through hydroxylation, dehydrogenation and carboxylation, and the presence of HA led to a stronger destruction of LF. This study helps better understand the degradation of organic micropollutants by $\mathrm{MnO}_{4}^{-}$in drinking water treatment.
\end{abstract}

(C) 2017 Elsevier Ltd. All rights reserved.

\section{Introduction}

Levofloxacin (LF) is an important fluoroquinolone antibiotic for the treatment of bacterial infections (e.g., tuberculosis, acute bacterial sinusitis, pneumonia) of humans and even HIV-affected patients (Goodwin et al., 1994; Mittmann et al., 2002). However, LF is mostly excreted through urine with only 15-20\% metabolism in human body (Wong et al., 1997). Moreover, fluoroquinolones are degraded very ineffectively in wastewater treatment plants (Yuan et al., 2015), and thus are eventually released into aquatic environments through effluent discharge and sludge disposal. As a result, LF has been frequently detected in surface waters with concentrations usually at $\mathrm{ng} \mathrm{L}^{-1}$ level (Conley et al., 2008; Kim et al., 2009). In particular, its occurrence in drinking water sources has attracted public concerns.

At drinking water treatment plants, permanganate $\left(\mathrm{MnO}_{4}^{-}\right)$is a commonly-used oxidant to remove taste and odor, enhance

\footnotetext{
* Corresponding author.

E-mail address: qiangz@rcees.ac.cn (Z. Qiang).
}

coagulation via producing $\mathrm{MnO}_{2}(\mathrm{~s})$, and reduce the formation of disinfection byproducts via oxidizing their precursors (Jiang et al., 2009; Sharma et al., 2012). In addition, $\mathrm{MnO}_{4}^{-}$can also oxidize organic micropollutants present in water and the oxidation reaction is selective depending on the electron density of certain moieties of a micropollutant. For example, the second-order rate constants $(k)$ for the reactions of $\mathrm{MnO}_{4}^{-}$with salbutamol and sulfamethoxazole were reported to be 283 and $0.11 \mathrm{M}^{-1} \mathrm{~s}^{-1}$ at $\mathrm{pH} 7$, respectively, which show a great difference (Rodríguez-Álvarez et al., 2015; Zhang et al., 2015). As the pH increased, even though the redox potential of $\mathrm{Mn}(\mathrm{VII})$ decreased, the reactivity of $\mathrm{MnO}_{4}^{-}$ toward phenol, lincomycin and sulfamethoxazole increased (Hu et al., 2010; Du et al., 2012; Gao et al., 2014), but the reactivity toward trimethoprim decreased (Hu et al., 2010). Therefore, the redox potential of $\mathrm{Mn}(\mathrm{VII})$ and the $\mathrm{p} K_{\mathrm{a}}$ values of an organic micropollutant can both affect the reaction rate in an aqueous solution.

As a typical natural organic matter in drinking water sources, humic acid (HA) was found to enhance the degradation of phenol, $17 \beta$-estradiol and triclosan (He et al., 2009; Jiang et al., 2009, 2012), inhibited sulfamethoxazole degradation (Gao et al., 2014), and had little impact on carbamazepine degradation (Hu et al., 2009) during 
$\mathrm{MnO}_{4}^{-}$oxidation. Several mechanisms have been proposed for the accelerated degradation of organic micropollutants by $\mathrm{MnO}_{4}^{-}$in the presence of HA: (1) HA forms a complex with the reaction intermediate $\mathrm{Mn}(\mathrm{III})$ as a ligand, preventing the disproportionation of $\mathrm{Mn}(\mathrm{III})$, and the complex continues to oxidize an organic micropollutant at a fast rate (Jiang et al., 2010); (2) HA increases the electron density of an organic micropollutant, thus accelerating its degradation by $\mathrm{MnO}_{4}^{-}$(He et al., 2009); and (3) the in-situ produced $\mathrm{MnO}_{2}$ (s) from the reaction of $\mathrm{MnO}_{4}^{-}$with HA oxidizes an organic micropollutant faster than the ex-situ $\mathrm{MnO}_{2}$ (s) (Sun et al., 2013). It is seen that HA has different impacts on the degradation of organic micropollutants by $\mathrm{MnO}_{4}^{-}$in water, and thus the reaction mechanism needs further investigation.

This study was to investigate the impact of HA on LF degradation by aqueous $\mathrm{MnO}_{4}^{-}$in the following aspects: (1) determine the kinetics of $\mathrm{LF}$ degradation by $\mathrm{MnO}_{4}^{-}$in the absence of $\mathrm{HA}$; (2) determine the kinetics of $\mathrm{LF}$ degradation by $\mathrm{MnO}_{4}^{-}$in the presence of $\mathrm{HA}$; (3) clarify the mechanism for HA accelerating LF degradation through secondary oxidant scavenging and electron paramagnetic resonance (EPR) tests; and (4) propose the degradation pathways of LF in the absence and presence of HA based on identified byproducts. This study helps better understand the degradation of organic micropollutants by $\mathrm{MnO}_{4}^{-}$in drinking water treatment.

\section{Materials and methods}

\subsection{Chemicals}

Milli-Q water (Advantage A10, Millipore, USA) was used in all experiments and analytical determinations. $\mathrm{KMnO}_{4}(99.5 \%)$ was purchased from Sinopharm Chemical Reagent (China), LF (98\%) from Tokyo Chemical Industry (Japan), HA (technical grade) and 5,5-dimethyl-1-pyrroline $N$-oxide (DMPO, 97\%) from SigmaAldrich (Germany), and 5-tert-butoxycarbonyl-5-methyl-1pyrroline $\mathrm{N}$-oxide (BMPO, 99\%) from Dojindo (Japan). All other chemicals were of analytical grade or higher. As the spin-trapping agents for radicals, DMPO, BMPO and their aqueous stock solutions were stored in a refrigerator at $-20{ }^{\circ} \mathrm{C}$. A freshly prepared $\mathrm{MnO}_{4}^{-}$stock solution (10 mM) was used for no more than 3 days and stored at $4{ }^{\circ} \mathrm{C}$ in the dark. HA stock solution was prepared by double filtering an aqueous HA suspension through $0.2-\mu \mathrm{m}$ membrane filters. Solution $\mathrm{pH}$ was buffered with $1 \mathrm{mM}$ phosphate and then adjusted with $\mathrm{NaOH}$ and $\mathrm{H}_{2} \mathrm{SO}_{4}$ solutions. The phosphate buffer had little effect on $\mathrm{LF}$ degradation by $\mathrm{MnO}_{4}^{-}$, and the change of $\mathrm{pH}$ was insignificant over the reaction course.

\subsection{Analytical methods}

LF was quantified with ultra-performance liquid chromatography-tandem mass spectrometry (UPLC-MS/MS, 1290 Infinity LC, 6420 Triple Quad MS, Agilent, USA) coupled with an SBC18 column $(2.1 \times 50 \mathrm{~mm}, 1.8 \mu \mathrm{m}$, Agilent, USA). The mobile phases consisted of $0.2 \%$ formic acid in water (A) and acetonitrile (B) (v/ $\mathrm{v}=60: 40$ ) at a total flow rate of $0.2 \mathrm{~mL} \mathrm{~min}^{-1}$. The MS system, operated in positive electrospray ionization $\left(\mathrm{ESI}^{+}\right)$mode, was set as follows: capillary voltage $4.0 \mathrm{kV}$, drying gas temperature $300{ }^{\circ} \mathrm{C}$, drying gas flow rate $10 \mathrm{~L} \mathrm{~min}^{-1}$, and nebulizing gas pressure $35 \mathrm{psi}$.

Electron paramagnetic resonance (EPR) spectra were recorded at ambient temperature (about $20^{\circ} \mathrm{C}$ ) in duplicate or triplicate on a Bruker A300-10/12 EPR spectrometer. It was operated at $9.8 \mathrm{GHz}$ of microwave bridge $\mathrm{X}$-band and $100 \mathrm{kHz}$ of modulation frequency. After the $\mathrm{MnO}_{4}^{-}$solution was added to initiate the reaction in a 2$\mathrm{mL}$ glass vial, the reaction solution was mixed immediately and inhaled into a clean capillary tube $(0.5 \mathrm{~mm} \times 10 \mathrm{~cm}$, with both ends open). The solution in the tube should fill the test window in the
EPR system. The tube was then blocked immediately with glycerol at one end, placed into a quartz tube, and inserted into the test cavity on the EPR system. The spectrum was recorded at a preselected reaction time. The operational parameters for testing the EPR adducts are listed in Text S1.

The degradation byproducts of LF were identified with ultraperformance liquid chromatography-tandem quadrupole time-offlight mass spectrometry (UPLC-QTOF-MS/MS, AcQuity LC, Xevo G2 QTOF MS, Waters, USA) coupled with an Eclipse Plus C18 column $(2.1 \times 150 \mathrm{~mm}, 3.5 \mu \mathrm{m}$, Agilent, USA). The mobile phases consisted of $0.2 \%$ formic acid in water (A) and acetonitrile (B) at a total flow rate of $0.2 \mathrm{~mL} \mathrm{~min}^{-1}$. The gradient elution program (time in $\mathrm{min}, \%$ mobile phase B) was set as follows: $(0,10),(20,90)$, and $(25,10)$. The MS system was operated in the $\mathrm{ESI}^{+}$mode with the following settings: capillary voltage $3 \mathrm{kV}$, cone voltage $30 \mathrm{~V}$, source temperature $100{ }^{\circ} \mathrm{C}$, desolvation temperature $280^{\circ} \mathrm{C}$, desolvation gas flow rate $500 \mathrm{~L} \mathrm{~h}^{-1}$, and MS/MS collision energy 15-35 eV.

Solution absorbance was measured by a UV-Vis spectrophotometer (DR6000, Hach, USA), and total organic carbon (TOC) was measured by a TOC- $\mathrm{V}_{\mathrm{CPH}}$ Analyzer (Shimadzu, Japan). The quantification of inorganic ions and low-molecular-weight organic acids is detailed in Text S1.

\subsection{Experimental procedures}

Under the pseudo-first-order conditions for LF degradation by $\mathrm{MnO}_{4}^{-}$(i.e., $\left[\mathrm{MnO}_{4}^{-}\right]_{0}:[\mathrm{LF}]_{\mathrm{o}}>10: 1$ ), the degradation kinetics and mechanism of LF were comparatively investigated in the absence and presence of HA. By using tert-butanol (TBA) and $p$-benzoquinone $(\mathrm{BQ})$ to respectively scavenge hydroxyl radicals $(\cdot \mathrm{OH})$ and superoxide radicals $\left(\mathrm{O}_{2} \cdot^{-}\right)$and sodium pyrophosphate (PP, $\mathrm{Na}_{4} \mathrm{P}_{2} \mathrm{O}_{7}$ ) as a ligand to complex $\mathrm{Mn}(\mathrm{III})$, the mechanism of $\mathrm{HA}$ accelerating $\mathrm{LF}$ degradation by $\mathrm{MnO}_{4}^{-}$was examined. Experiments were conducted in triplicate in $50-\mathrm{mL}$ conical flasks with magnetic stirring at ambient temperature $\left(20 \pm 2{ }^{\circ} \mathrm{C}\right)$. After a certain amount of $\mathrm{MnO}_{4}^{-}$stock solution was added to the reaction solution containing other reactants with $\mathrm{pH}$ pre-adjusted, water samples were withdrawn at preselected times, immediately quenched with an excessive $\mathrm{Na}_{2} \mathrm{~S}_{2} \mathrm{O}_{3}$, and filtered by $0.2-\mu \mathrm{m}$ membrane filters. HA was quantified in terms of TOC concentration, and $[\mathrm{HA}]_{0}:\left[\mathrm{KMnO}_{4}\right]_{\mathrm{o}}$ represented the initial mass ratio of $\mathrm{HA}_{\mathrm{TOC}}$ to $\mathrm{KMnO}_{4}$. By contrast, molar ratio was used for all other reactants with known molecular weights. To identify the degradation byproducts of LF formed during $\mathrm{MnO}_{4}^{-}$oxidation, higher concentrations of $\mathrm{MnO}_{4}^{-}(2800 \mu \mathrm{M})$, LF $(28 \mu \mathrm{M})$ and HA were purposely adopted for more accurate quantifications, but their concentrations were raised proportionally.

$\mathrm{MnO}_{4}^{-}$solution has a maximum absorbance at $525 \mathrm{~nm}\left(\mathrm{~A}_{525}\right)$ (Waldemer and Tratnyek, 2006). Under the pseudo-first-order conditions for $\mathrm{MnO}_{4}^{-}$consumption by $\mathrm{LF}\left([\mathrm{LF}]_{0}:\left[\mathrm{MnO}_{4}^{-}\right]_{0}=10: 1\right)$, the reaction rate constant of $\mathrm{LF}_{\text {with }} \mathrm{MnO}_{4}^{-}$was also determined by measuring the decay of $A_{525}$. Experiments were conducted in triplicate in a $1-\mathrm{cm}$ quartz cuvette at ambient temperature $\left(20 \pm 2{ }^{\circ} \mathrm{C}\right)$. After a certain amount of $\mathrm{MnO}_{4}^{-}$stock solution was added, the reaction solution $(3 \mathrm{~mL})$ was immediately mixed with a clean pipette tip and then the decay of $\mathrm{A}_{525}$ was monitored continuously.

\section{Results and discussion}

\subsection{Reaction kinetics of $\mathrm{LF}$ with $\mathrm{MnO}_{4}^{-}$}

The degradation of LF followed a pseudo-first-order kinetics with $\mathrm{MnO}_{4}^{-}$in 200-fold excess (Fig. 1a), indicating that the reaction was of first-order with respect to LF. Meanwhile, at a fixed initial LF 

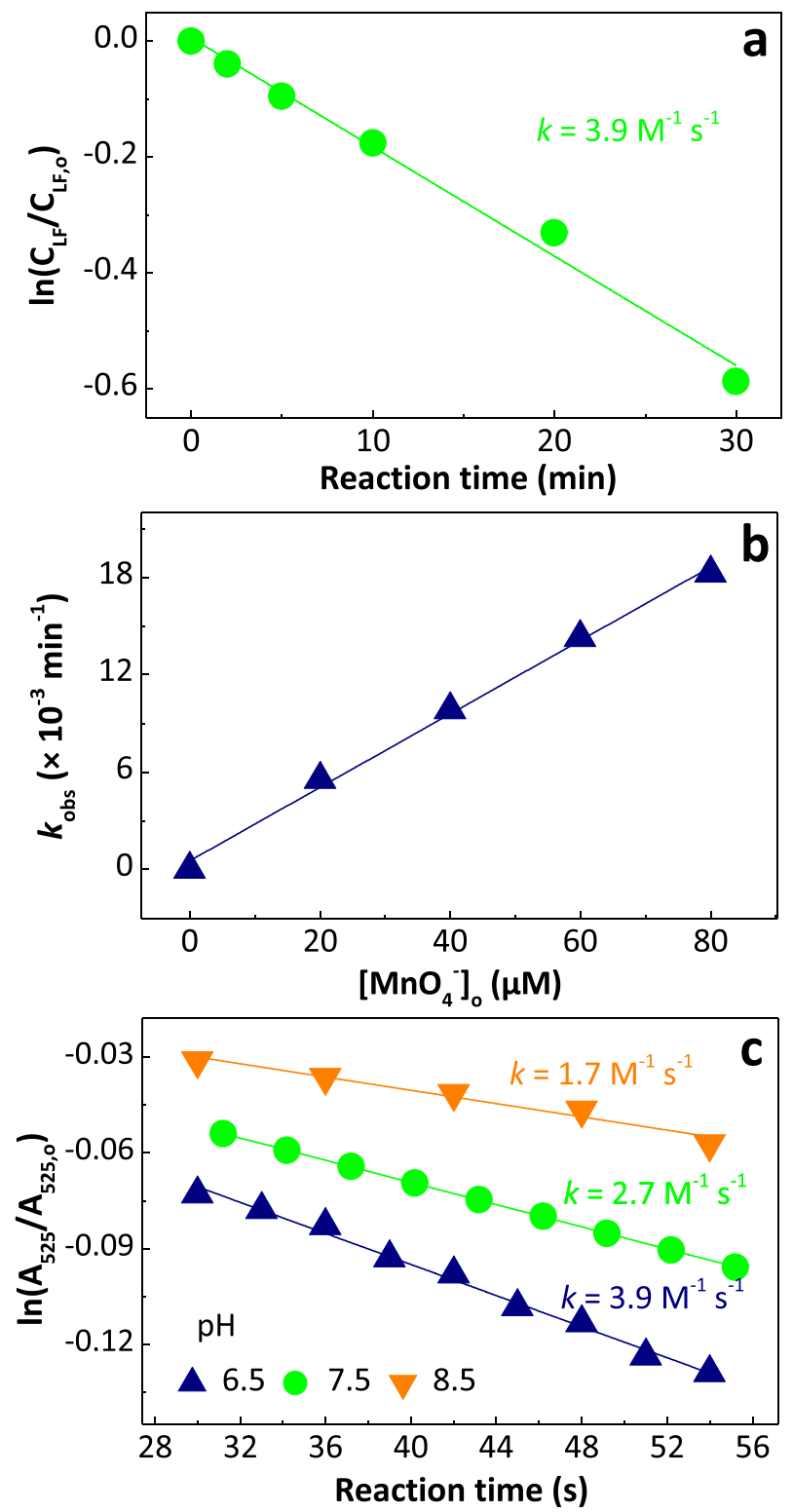

Fig. 1. Kinetics of LF degradation by $\mathrm{MnO}_{4}^{-}$: (a) plot of $\ln \left(\mathrm{C}_{\mathrm{LF}} / \mathrm{C}_{\mathrm{LF}, \mathrm{o}}\right)$ vs. time; (b) plot of $k_{\text {obs }}$ vs. $\left[\mathrm{MnO}_{4}^{-}\right]_{\mathrm{o}}$; and (c) plot of $\ln \left(\mathrm{A}_{525} / \mathrm{A}_{525, \mathrm{o}}\right)$ vs. time. Experimental conditions: (a) $\left[\mathrm{MnO}_{4}^{-}\right]_{\mathrm{o}}=80 \mu \mathrm{M},[\mathrm{LF}]_{\mathrm{o}}=0.4 \mu \mathrm{M}, \mathrm{pH}=7.5$; (b) $[\mathrm{LF}]_{\mathrm{o}}=0.4 \mu \mathrm{M}, \mathrm{pH}=7.5$; and (c) $\left[\mathrm{MnO}_{4}^{-}\right]_{\mathrm{o}}=63 \mu \mathrm{M},[\mathrm{LF}]_{\mathrm{o}}=630 \mu \mathrm{M}$. The standard deviation for all data points is below $5 \%$.

concentration, the pseudo-first-order rate constant $\left(k_{\mathrm{obs}}, \mathrm{min}^{-1}\right)$ increased linearly with increasing $\mathrm{MnO}_{4}^{-}$concentration (Fig. 1b), indicating that the reaction was also of first-order with respect to $\mathrm{MnO}_{4}^{-}$. Therefore, the reaction kinetics of $\mathrm{LF}$ with $\mathrm{MnO}_{4}^{-}$can be expressed by Eq. (1):

$$
-\frac{\mathrm{d}[\mathrm{LF}]}{\mathrm{dt}}=k_{\mathrm{obs}}[\mathrm{LF}]=k\left[\mathrm{MnO}_{4}^{-}\right][\mathrm{LF}]
$$

where $k$ is the second-order rate constant, which was determined to be $3.9 \mathrm{M}^{-1} \mathrm{~s}^{-1}$ at $\mathrm{pH} 7.5$.

Under the pseudo-first-order condition for $\mathrm{MnO}_{4}^{-}$consumption, the decay of $\mathrm{A}_{525}$ in the $\mathrm{MnO}_{4}^{-} / \mathrm{LF}$ system was monitored in the early reaction phase. The consumption of $\mathrm{MnO}_{4}^{-}$at $\mathrm{pH} 7.5$ followed the pseudo-first-order kinetics with LF in 10-fold excess and a $k$ value of $2.7 \mathrm{M}^{-1} \mathrm{~s}^{-1}$ was obtained (Fig. 1c). This value is a little lower than that obtained with $\mathrm{MnO}_{4}^{-}$in excess $\left(k=3.9 \mathrm{M}^{-1} \mathrm{~s}^{-1}\right)$, probably because the colloidal $\mathrm{MnO}_{2}(\mathrm{~s})$ and some organic intermediates produced from the reaction of $\mathrm{MnO}_{4}^{-}$with $\mathrm{LF}$ had a certain contribution to the $\mathrm{A}_{525}$. In addition, a decrease of $\mathrm{pH}$ to 6.5 accelerated the $\mathrm{MnO}_{4}^{-}$consumption, while an increase of $\mathrm{pH}$ to 8.5 hindered the $\mathrm{MnO}_{4}^{-}$consumption (Fig. 1c), indicating that the reactivity of $\mathrm{LF}$ with $\mathrm{MnO}_{4}^{-}$increased as $\mathrm{pH}$ decreased. The $\mathrm{p} K_{\mathrm{a}}$ values associated with the $\mathrm{N}_{1}$ atom, carboxylic group and $\mathrm{N}_{4}$ atom in the chemical structure of LF (Fig. S1) are 5.2, 6.2 and 8.2, respectively (De Witte et al., 2009). When the pH decreased from 8.5 to 6.5 , the $\mathrm{N}_{4}$ atom was protonated, which enhanced its electron-withdrawing ability from adjacent groups (Hu et al., 2010) including the side $-\mathrm{CH}_{3}$ and the $-\mathrm{C}-\mathrm{C}-$ bond in the piperazinyl moiety (Fig. S1). As can be seen from the degradation pathways of LF proposed later (Section 3.5), the side $-\mathrm{CH}_{3}$ group was hydroxylated and the $-\mathrm{C}-\mathrm{C}-$ bond was dehydrogenated to form $-\mathrm{C}=\mathrm{C}-$ (LF375(1)), thus both were the primary reaction sites. The olefin structure $\left(-\mathrm{C}=\mathrm{C}-\right.$ ) tended to further react with $\mathrm{MnO}_{4}^{-}$by forming a $3+2$ cyclic diester intermediate (Hu et al., 2010), and then the two carbon atoms in the olefin structure could be eliminated to form LF335(2), or one was eliminated and the other hydroxylated to form LF385. Thus, as the $\mathrm{pH}$ decreased, the $\mathrm{N}_{4}$ atom facilitated the degradation of LF and some byproducts as well by enhancing the electrophilicity of structural groups adjacent to $\mathrm{N}_{4}$.

\subsection{Impact of $\mathrm{HA}$ on $\mathrm{LF}$ degradation by $\mathrm{MnO}_{4}^{-}$}

At $\mathrm{pH} 7.5$, the $k_{\mathrm{obs}}$ values of LF degradation were significantly enhanced by 3.8- and 2.8-fold at $[\mathrm{HA}]_{0}:\left[\mathrm{KMnO}_{4}\right]_{\mathrm{o}}=0.5$ and 1 , respectively, as compared to that in the absence of $\mathrm{HA}$ (Fig. 2a). The mass ratios of $[\mathrm{HA}]_{\mathrm{o}}:\left[\mathrm{KMnO}_{4}\right]_{\mathrm{o}}$ of 0.5 and 1 were purposely selected because both the TOC concentration of raw water and the $\mathrm{KMnO}_{4}$

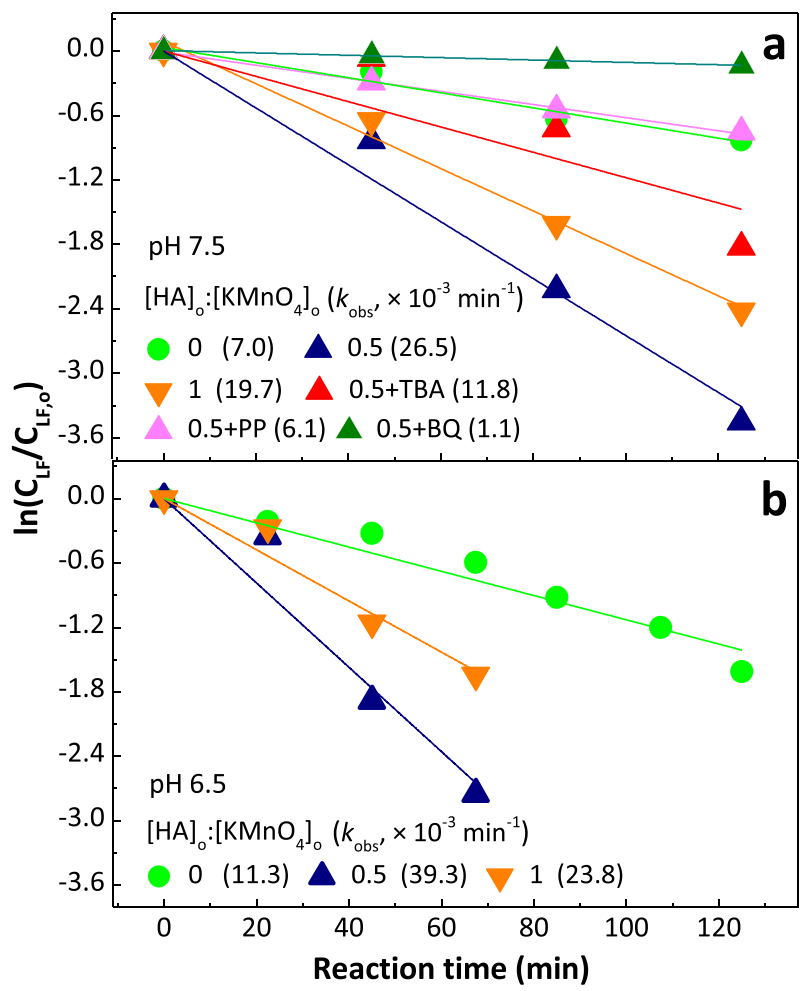

Fig. 2. Impact of $\mathrm{HA}$ on $\mathrm{LF}$ degradation by $\mathrm{MnO}_{4}^{-}$at: (a) $\mathrm{pH}=7.5$; and (b) $\mathrm{pH}=6.5$. Experimental conditions: $\left[\mathrm{MnO}_{4}^{-}\right]_{\mathrm{o}}=40 \mu \mathrm{M},[\mathrm{LF}]_{\mathrm{o}}=0.4 \mu \mathrm{M},[\mathrm{TBA}]_{\mathrm{o}}=2.7 \mathrm{mM}$, $[\mathrm{PP}]_{\mathrm{o}}=1 \mathrm{mM},[\mathrm{BQ}]_{\mathrm{o}}=20 \mu \mathrm{M}$. The standard deviation for all data points is below $10 \%$. 
dose are usually in the same range (i.e., $1-3 \mathrm{mg} \mathrm{L}^{-1}$ ) in drinking water treatment. It was reported that at $[\mathrm{HA}]_{0}:\left[\mathrm{KMnO}_{4}\right]_{0}<1, \mathrm{HA}$ also enhanced the degradation of phenol, $17 \beta$-estradiol and triclosan by $\mathrm{MnO}_{4}^{-}$(He et al., 2009; Jiang et al., 2009, 2012). However, when the $[\mathrm{HA}]_{\mathrm{o}}:\left[\mathrm{KMnO}_{4}\right]_{\mathrm{o}}$ ratio increased to 2-5, HA inhibited the degradation of sulfamethoxazole by $\mathrm{MnO}_{4}^{-}$(Gao et al., 2014), most probably because an excessive HA could not only consume more $\mathrm{MnO}_{4}^{-}$but also strongly compete for secondary oxidants produced from the reaction between $\mathrm{HA}$ and $\mathrm{MnO}_{4}^{-}$.

Results further show that at $[\mathrm{HA}]_{0}:\left[\mathrm{KMnO}_{4}\right]_{\mathrm{o}}=0.5$, the addition of TBA inhibited about $75 \%$ of the acceleration of LF degradation (Fig. 2a), but TBA itself had little impact on LF degradation (Fig. S2), which indicates that $\cdot \mathrm{OH}$ contributed primarily to the acceleration. $\mathrm{PP}$ is a specific ligand for $\mathrm{Mn}(\mathrm{III})$, which prevents the spontaneous disproportionation of $\mathrm{Mn}(\mathrm{III})$ to $\mathrm{MnO}_{2}$ (s) and $\mathrm{Mn}$ (II) (Sun et al., 2015). The addition of PP completely inhibited the acceleration of LF degradation at $[\mathrm{HA}]_{0}:\left[\mathrm{KMnO}_{4}\right]_{\mathrm{o}}=0.5$ (Fig. 2a), but PP itself did not inhibit LF degradation (Fig. S2), which indicates that Mn(III) was an initially decisive intermediate causing the acceleration of LF degradation since the effect of $\bullet \mathrm{OH}$ was totally shielded. In addition, this result also implies that $\mathrm{Mn}(\mathrm{III})$ should have induced the production of $\cdot \mathrm{OH}$ in the presence of $\mathrm{HA}$.

BQ is often used to scavenge $\mathrm{O}_{2}{ }^{-}$(Cavalcante et al., 2016). At $[\mathrm{HA}]_{0}:\left[\mathrm{KMnO}_{4}\right]_{\mathrm{o}}=0.5$, the addition of $\mathrm{BQ}$ almost terminated the oxidation of $\mathrm{LF}$ by $\mathrm{MnO}_{4}^{-}$(Fig. $2 \mathrm{a}, k_{\mathrm{obs}}=1.1 \times 10^{-3} \mathrm{~min}^{-1}$ ), whereas BQ itself did not inhibit but obviously accelerated LF degradation (Fig. S2), which suggests the existence of $\mathrm{O}_{2}{ }^{-}{ }^{-}$. It was reported that BQ could effectively accelerate the oxidation of sulfamethoxazole by peroxymonosulfate, which was attributed to a catalytic intermediate (dioxirane) produced in the reaction of peroxymonosulfate with BQ (Zhou et al., 2015). The mechanism for the remarkable enhancement of $\mathrm{BQ}$ on $\mathrm{LF}$ degradation by $\mathrm{MnO}_{4}^{-}$observed in this study warrants further investigation. In addition, Fig. 2a also suggests that the reactivity of $\mathrm{MnO}_{4}^{-}$with $\mathrm{BQ}$ was lower than that of $\mathrm{O}_{2}{ }^{--}$with BQ (ca. $1.0 \times 10^{9} \mathrm{M}^{-1} \mathrm{~s}^{-1}$ ) (Cavalcante et al., 2016).

The reaction of $\mathrm{MnO}_{4}^{-}$with $\mathrm{HA}$ could induce chemiluminescence (Marino and Ingle, 1981). In addition, the chemiluminescence was applied to monitor the evolution of oxygen radicals (Henry et al., 1990), and the dismutation of peroxy radicals could produce chemiluminescence (Sławiński, 1988). As mentioned above, the degradation of LF, phenol, $17 \beta$-estradiol and triclosan by $\mathrm{MnO}_{4}^{-}$ could all be enhanced by HA. Combined with the results shown in Fig. 2a, it can be inferred that oxygen-centered radicals were produced in the reaction of $\mathrm{MnO}_{4}^{-}$with HA. Jiang et al. (2010) proposed that HA could form a complex with $\mathrm{Mn}(\mathrm{III})$ to prevent its disproportionation and thus maintain its strong oxidation ability for organic micropollutants, but they did not test the formation of radicals. In this study, it was found that $\cdot \mathrm{OH}$ actually played a primary role in accelerating the degradation of $\mathrm{LF}$ by $\mathrm{MnO}_{4}^{-}$(i.e., about $75 \%$ ), and this radical originated from $\mathrm{Mn}(\mathrm{III})$ in the presence of $\mathrm{HA}$. Therefore, the following reaction (Eq. (2)) can be hypothesized:

$2[\mathrm{HA}-\mathrm{Mn}(\mathrm{III})]+\mathrm{O}_{2}+2 \mathrm{H}_{2} \mathrm{O} \rightarrow 2 \mathrm{Mn}(\mathrm{II})+2 \mathrm{O}_{2}^{--}+4 \mathrm{H}^{+}+2 \mathrm{HA}$

The superoxide radical $\left(\mathrm{O}_{2}{ }^{-}\right)$, once formed, can disproportionate in water very quickly to produce $\cdot \mathrm{OH}$ according to Eqs. (3)-(4):

$\mathrm{O}_{2}^{--}+\mathrm{H}_{2} \mathrm{O} \rightarrow \mathrm{HO}_{2}^{\cdot}+\mathrm{OH}^{-}$

$\mathrm{HO}_{2}^{\cdot}+\mathrm{H}_{2} \mathrm{O} \rightarrow \cdot \mathrm{OH}+\mathrm{H}_{2} \mathrm{O}_{2}$

Because of the strong oxidation ability of $\cdot \mathrm{OH}$, it was primarily contributive to the accelerated LF degradation; in the meanwhile, the complex [HA-Mn(III)] could account for the rest of acceleration. Due to a great difference between the water and LF concentrations and its relatively weaker oxidation ability, $\mathrm{O}_{2}{ }^{-}$was unlikely to accelerate the LF degradation.

Fig. 2 b shows that at $\mathrm{pH} 6.5$ and $[\mathrm{HA}]_{0}:\left[\mathrm{KMnO}_{4}\right]_{0}=0.5$ and 1 , the degradation rates of LF were increased by $48 \%$ and $21 \%$ as compared to those at $\mathrm{pH} 7.5$, respectively. The more acidic $\mathrm{pH}$ could enhance the disproportionation of $\mathrm{O}_{2}{ }^{-}$to produce $\cdot \mathrm{OH}$ (i.e., Eqs. (3)-(4)), thus promoting the degradation of LF.

\subsection{Evidence for $\mathrm{O}_{2}{ }^{-}$formation in the reaction of $\mathrm{MnO}_{4}^{-}$with $\mathrm{HA}$}

EPR spectroscopy is commonly utilized to test radical formation by using either a nitrone (e.g., DMPO, BMPO) or a nitroso to trap the radical as a longer-lived nitroxide (Finkelstein et al., 1980). Compared to the common spin trapping agent DMPO, BMPO is more suitable to trap $\mathrm{O}_{2}{ }^{--}$due to the longer half-life of the resulting BMPO-OOH (Zhang et al., 2000; Tsai et al., 2003). In this test, a large amount of methanol $\left(\mathrm{CH}_{3} \mathrm{OH}, 14 \mathrm{M}\right)$ should be applied to prevent the complete disproportionation of $\mathrm{O}_{2}{ }^{\cdot-}$ so that a certain amount of $\mathrm{O}_{2}{ }^{--}$can be trapped by BMPO. In the absence of HA, both BMPO$\mathrm{OOH}$ and BMPO-OH were identified in the $\mathrm{MnO}_{4}^{-} / \mathrm{BMPO} / \mathrm{CH}_{3} \mathrm{OH}$ system, implying the production of $\mathrm{O}_{2}{ }^{--}$and $\cdot \mathrm{OH}$ (Fig. 3). BMPO$\mathrm{OOH}$ could only be produced through the genuine spin trapping of $\mathrm{O}_{2}{ }^{--}$by BMPO (Fig. S3a). Because water also existed in the reaction system, a part of $\mathrm{O}_{2}{ }^{-}$could disproportionate to form $\cdot \mathrm{OH}$ (Eqs. (3)-(4)), which was then trapped by BMPO to form BMPO-OH (Fig. S3b). In addition, BMPO-OH may also be produced from the direct oxidation of BMPO by $\mathrm{MnO}_{4}^{-}$without radical formation (Fig. S3b). As the $[\mathrm{HA}]_{0}:\left[\mathrm{KMnO}_{4}\right]_{0}$ ratio increased from 0 to $1,1.5$ and 2 , the intensity of BMPO-OOH increased quickly until exceeding that of BMPO-OH at $[\mathrm{HA}]_{\mathrm{O}}:\left[\mathrm{KMnO}_{4}\right]_{\mathrm{o}}=2$ (Fig. 3), demonstrating an increasing production of $\mathrm{O}_{2}{ }^{-}$in the reaction of $\mathrm{MnO}_{4}^{-}$with $\mathrm{HA}$.

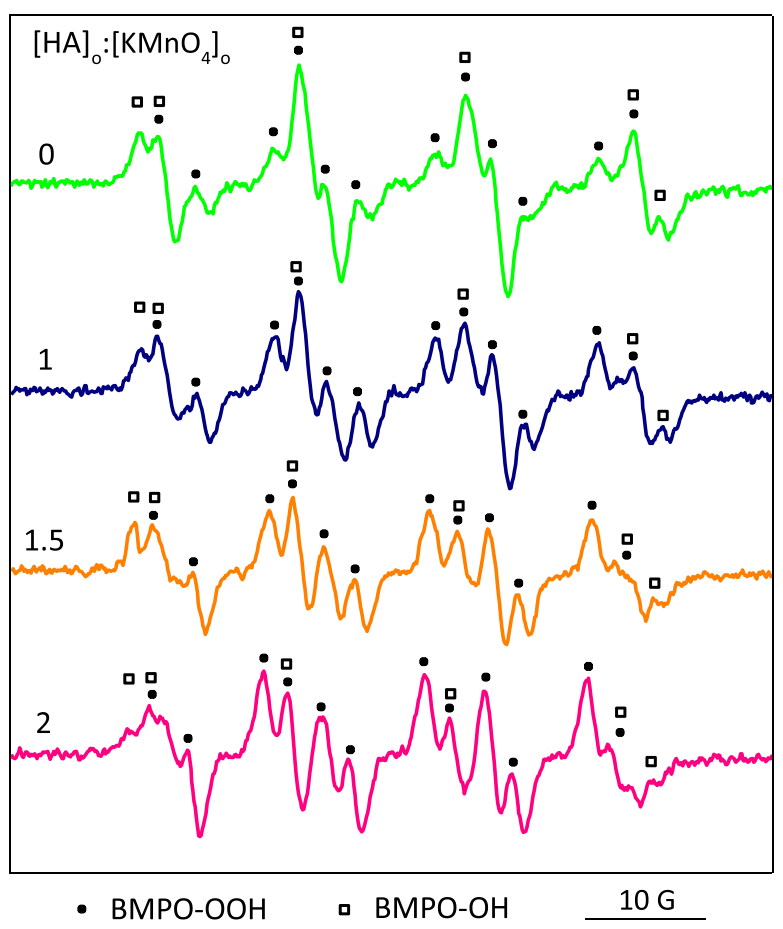

Fig. 3. EPR evidence for $\mathrm{O}_{2}{ }^{--}$production in the reaction of $\mathrm{MnO}_{4}^{-}$with $\mathrm{HA}$ at different $[\mathrm{HA}]_{0}:\left[\mathrm{KMnO}_{4}\right]_{0}$ ratios. Experimental conditions: $\left[\mathrm{MnO}_{4}^{-}\right]_{0}=200 \mu \mathrm{M}$, $[\mathrm{BMPO}]_{\mathrm{o}}=6.6 \mathrm{mM},[\text { methanol }]_{\mathrm{o}}=14 \mathrm{M}$. 


\subsection{Evidence for $\cdot \mathrm{OH}$ formation in the reaction of $\mathrm{MnO}_{4}^{-}$with $\mathrm{HA}$}

In the $\mathrm{MnO}_{4}^{-} / \mathrm{DMPO}$ system ([DMPO $\left.]_{0}:\left[\mathrm{MnO}_{4}^{-}\right]_{\mathrm{o}}=8.2\right)$, DMPOX was identified (Fig. 4a), which has the characteristic hyperfine splitting constants of $a_{\mathrm{N}}=7.2 \mathrm{G}$ and $a_{\mathrm{H}}=4.1 \mathrm{G}$ (Lawrence et al., 2003). Potential pathways for DMPOX formation included: (1) - $\mathrm{OH}$ production in the reaction of $\mathrm{MnO}_{4}^{-}$with an excessive DMPO, and subsequent DMPO-OH formation (through the genuine spin trapping of $\cdot \mathrm{OH}$ by DMPO) and its dehydrogenation by $\mathrm{MnO}_{4}^{-}$to DMPOX (Fig. S4a); and (2) direct oxidation of DMPO by $\mathrm{MnO}_{4}^{-}$to DMPO-OH and its subsequent dehydrogenation to DMPOX without radical formation (Fig. S4b).

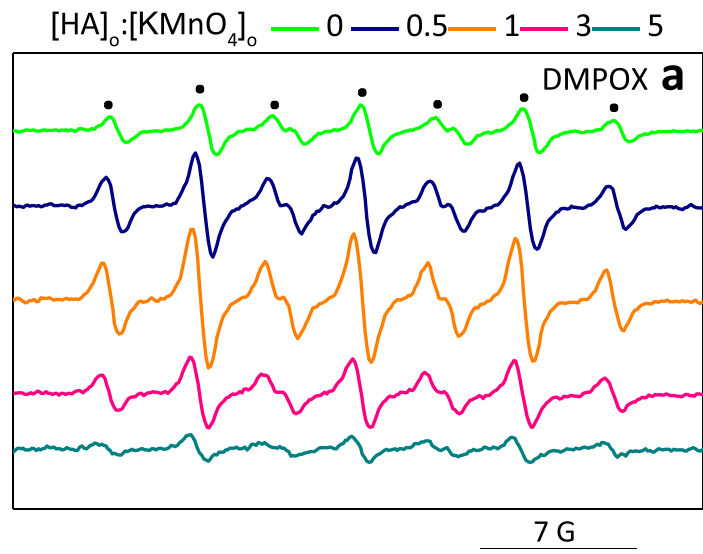

$[\mathrm{HA}]_{0}:\left[\mathrm{KMnO}_{4}\right]_{0}-0-0.5-1$
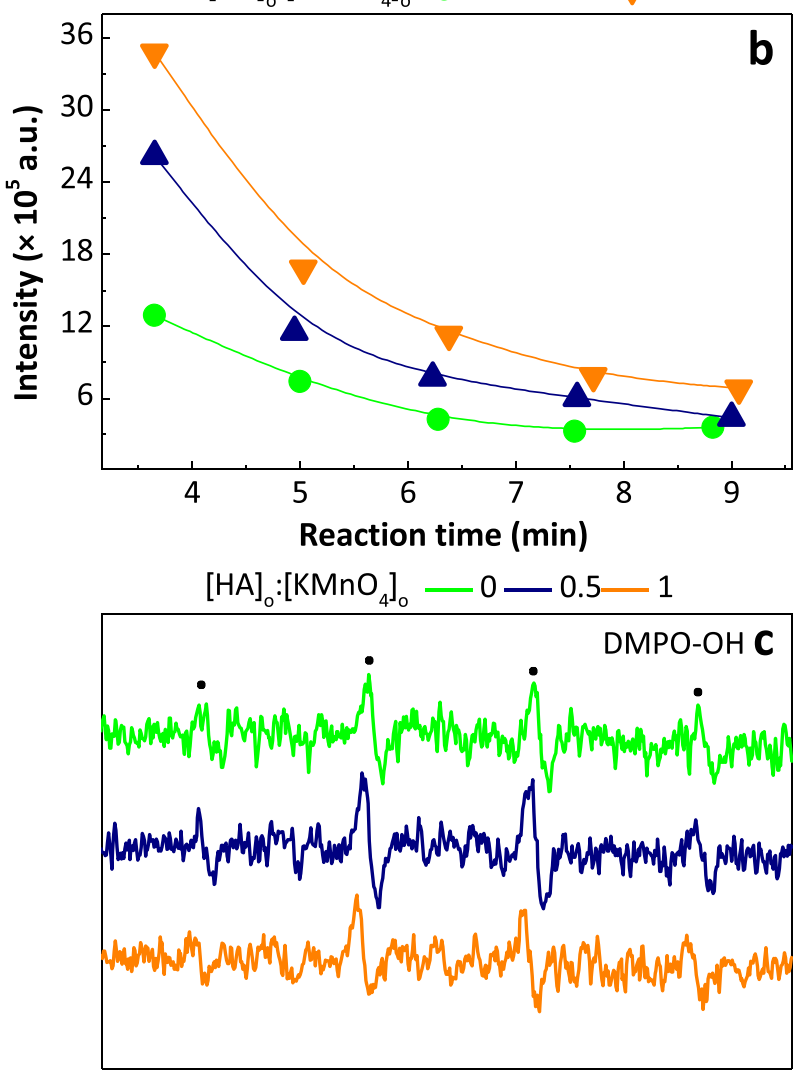

$10 \mathrm{G}$

Fig. 4. EPR evidence for ${ }^{\circ} \mathrm{OH}$ production in the reaction of $\mathrm{MnO}_{4}^{-}$with $\mathrm{HA}$ at different $[\mathrm{HA}]_{\mathrm{o}}:\left[\mathrm{KMnO}_{4}\right]_{\mathrm{o}}$ ratios: (a) spectra of DMPOX; (b) degradation kinetics of DMPOX; and (c) spectra of DMPO-OH. Experimental conditions: (a)/(b) $\left[\mathrm{MnO}_{4}^{-}\right]_{\mathrm{o}}=710 \mu \mathrm{M}$, $[\mathrm{DMPO}]_{\mathrm{o}}=5.82 \mathrm{mM}$; and $(\mathrm{c})\left[\mathrm{MnO}_{4}^{-}\right]_{\mathrm{o}}=100 \mu \mathrm{M},[\mathrm{DMPO}]_{\mathrm{o}}=50 \mathrm{mM}$.
At $[\mathrm{HA}]_{0}:\left[\mathrm{KMnO}_{4}\right]_{\mathrm{o}}=0.5,1$ and 3 , the intensity of DMPOX formed was enhanced by 2-, 2.8- and 1.4-fold, respectively, as compared to that in the absence of HA (Fig. 4a). At $[\mathrm{HA}]_{0}:\left[\mathrm{KMnO}_{4}\right]_{0}=5$, the formation of DMPOX was inhibited notably. This result indicates again the production of $\cdot \mathrm{OH}$ in the reaction of $\mathrm{MnO}_{4}^{-}$with $\mathrm{HA}$. At $[\mathrm{HA}]_{0}:\left[\mathrm{KMnO}_{4}\right]_{0}=3$ and 5 , the produced $\cdot \mathrm{OH}$ could be consumed by HA with a higher concentration more significantly. After DMPOX was produced in the absence of $\mathrm{HA}$, it could be further oxidized by $\mathrm{MnO}_{4}^{-}$(Fig. 4b). In the presence of HA, the oxidation rate of DMPOX was enhanced by 2.3- and 3.0 -fold at $[\mathrm{HA}]_{0}:\left[\mathrm{KMnO}_{4}\right]_{\mathrm{o}}=0.5$ and 1 , respectively. This enhancement provides an additional evidence for the production of $\cdot \mathrm{OH}$ in the reaction of $\mathrm{MnO}_{4}^{-}$with $\mathrm{HA}$. The produced $\cdot \mathrm{OH}$ could not only oxidize DMPO to DMPOX (Fig. S4a) resulting in an increased initial intensity of DMPOX (Fig. 4b), but also further oxidize DMPOX resulting in its accelerated degradation (Fig. 4b).

Trapping $\cdot \mathrm{OH}$ by DMPO first produces DMPO-OH. An excessive DMPO can prevent all DMPO-OH produced from being dehydrogenated to DMPOX by $\mathrm{MnO}_{4}^{-}$. This is verified by the identification of DMPO-OH, which has the characteristic hyperfine splitting constants of $a_{\mathrm{N}}=a_{\mathrm{H}}=14.9 \mathrm{G}$ (Finkelstein et al., 1980), when the [DMPO $]_{0}:\left[\mathrm{MnO}_{4}^{-}\right]_{\mathrm{O}}$ ratio was increased to 500 in the absence of $\mathrm{HA}$ (Fig. 4c). In the presence of HA, the intensity of DMPO-OH was enhanced by 1.2 -fold at $[\mathrm{HA}]_{0}:\left[\mathrm{KMnO}_{4}\right]_{0}=0.5$, indicating once more that $\cdot \mathrm{OH}$ was produced in the reaction of $\mathrm{MnO}_{4}^{-}$with HA. At $[\mathrm{HA}]_{0}:\left[\mathrm{KMnO}_{4}\right]_{\mathrm{O}}=1$, the intensity of DMPO-OH decreased to some extent, because an increasing $\mathrm{HA}$ could consume more $\mathrm{MnO}_{4}^{-}$ and $\cdot \mathrm{OH}$.

As the $[\mathrm{HA}]_{0}:\left[\mathrm{KMnO}_{4}\right]_{\mathrm{o}}$ ratio increased from 0 to 0.5 , the enhanced LF degradation (Fig. 2) and the enhanced formation of DMPOX and DMPO-OH (Fig. 4) all indicate an increasing $\cdot \mathrm{OH}$ yield. As the $[\mathrm{HA}]_{0}:\left[\mathrm{KMnO}_{4}\right]_{0}$ ratio further increased to 1 , the formation of DMPOX was enhanced significantly (Fig. 4a), while the enhancement on LF degradation and DMPO-OH formation were both weakened. At $[\mathrm{HA}]_{\mathrm{o}}:\left[\mathrm{KMnO}_{4}\right]_{\mathrm{o}}=0.5$ and 1 , the different trends of DMPOX and DMPO-OH could be attributed to the different extents of DMPO oxidation by $\mathrm{MnO}_{4}^{-}$and $\bullet \mathrm{OH}$. The weakened acceleration of LF degradation at $[\mathrm{HA}]_{0}:\left[\mathrm{KMnO}_{4}\right]_{0}=1$ denotes a stronger consumption of $\mathrm{MnO}_{4}^{-}$and $\cdot \mathrm{OH}$ by $\mathrm{HA}$.

\subsection{Degradation pathways of LF in the absence and presence of $H A$}

Based on the total ion chromatograms of LF solution treated by $\mathrm{MnO}_{4}^{-}$(Fig. S5) and the evolution of the relative abundances of identified byproducts (Fig. S6) within the first $30 \mathrm{~min}$, the degradation pathways of LF in the absence of HA were proposed (Fig. 5). The mass measurements of protonated LF and byproducts as well as the $\mathrm{MS}^{2}$ spectra and proposed fragmentation patterns are detailed in Table 1 and Fig. S7, respectively. In addition, the evolution of TOC, inorganic ions and low-molecular-weight organic acids formed during $\mathrm{LF}$ degradation by $\mathrm{MnO}_{4}^{-}$was determined (Fig. S8).

Fig. S6 shows that as one of the initial degradation byproducts, LF375 (i.e., LF375(1) + LF375(2)) reached a peak of relative abundance at a reaction time of $2 \mathrm{~min}$. As mentioned above, the $\mathrm{N}_{4}$ atom in the chemical structure of LF could facilitate the formation of LF375(1) through hydroxylation of the side $-\mathrm{CH}_{3}$ group and dehydrogenation of the $-\mathrm{C}_{4^{\prime}}-\mathrm{C}_{5^{\prime}}-$ bond. If the $-\mathrm{CH}_{3}$ group (at the $\mathrm{C}_{1}$, site) was hydroxylated, LF375(2) could be formed. LF377(1) and LF377(2) were formed through hydroxylation of the $-\mathrm{CH}_{3}$ groups at the $\mathrm{C}_{6^{\prime}}$ and $\mathrm{C}_{1^{\prime}}$ sites, respectively. $\mathrm{MnO}_{4}^{-}$might also attack $\mathrm{LF}$ through dehydrogenation to produce LF359(1) and LF359(2). LF335(1) could originate from the removal of $-\mathrm{C}_{1^{\prime}}-\mathrm{C}_{2^{\prime}}-$ from LF377(2), and LF335(2) from the removal of $-C_{4^{\prime}}=C_{5^{\prime}}-$ from LF359(2), which both induced the formation of oxalate. The simultaneous removal of $\mathrm{C}_{4^{\prime}}$ and $\mathrm{C}_{5^{\prime}}$ was also reported during 


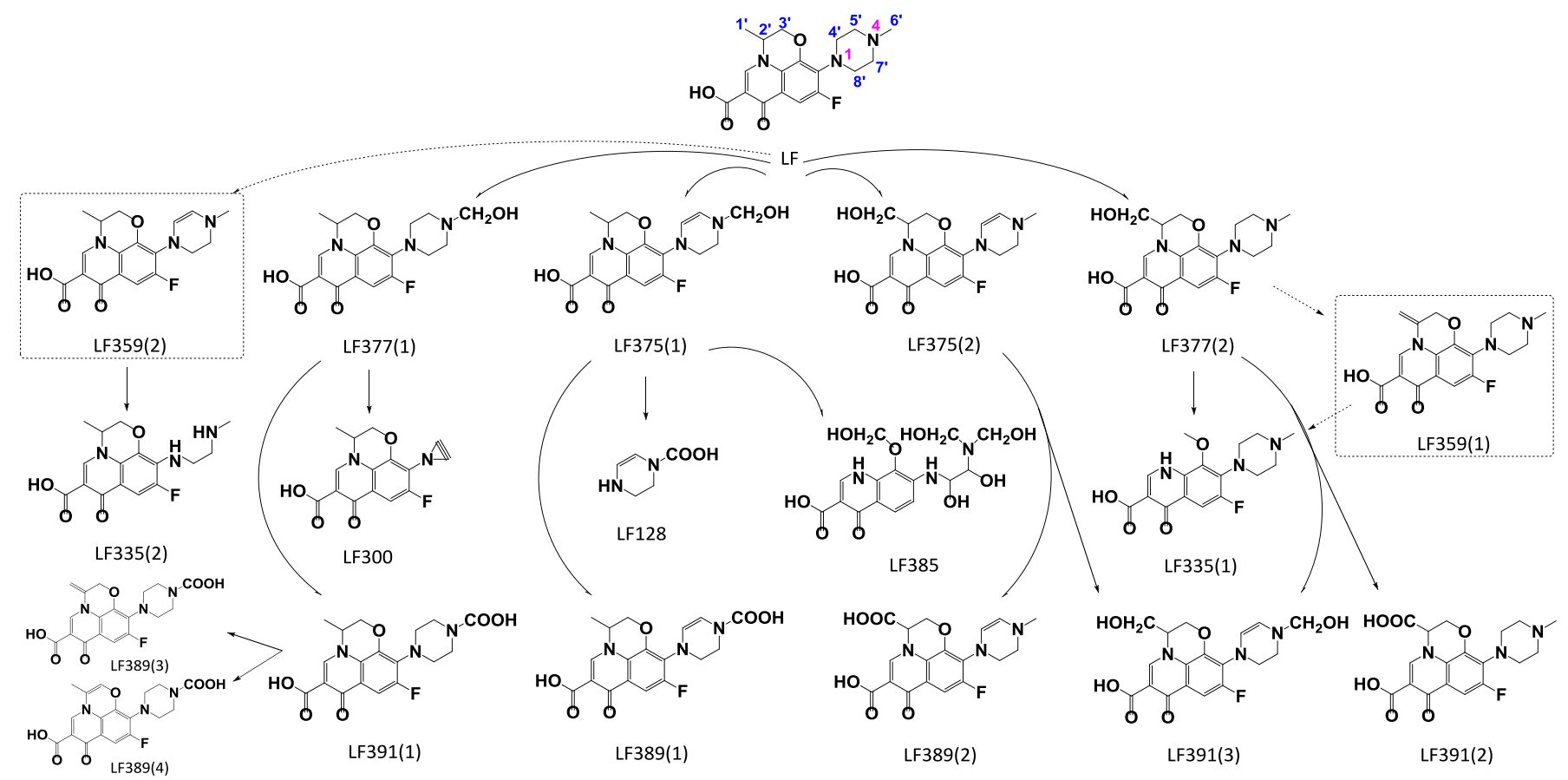

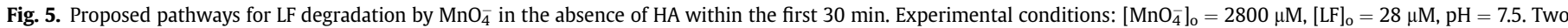
intermediates in the dashed boxes are speculated only.

Table 1

Mass measurements of protonated LF and byproducts in the MS and MS ${ }^{2}$ modes.

\begin{tabular}{|c|c|c|c|c|c|c|c|}
\hline Name & Elemental composition & Retention time (min) & Nominal ion mass $(\mathrm{m} / \mathrm{z})$ & Measured ion mass $(\mathrm{m} / \mathrm{z})$ & Calculated ion mass $(\mathrm{m} / \mathrm{z})$ & Mass error (ppm) & $\mathrm{DBE}^{\mathrm{a}}$ \\
\hline LF & $\mathrm{C}_{18} \mathrm{H}_{20} \mathrm{~N}_{3} \mathrm{O}_{4} \mathrm{~F}$ & $5.00-5.03$ & 362 & 362.1513 & 362.1511 & +0.6 & 9.5 \\
\hline LF375 & $\mathrm{C}_{18} \mathrm{H}_{18} \mathrm{~N}_{3} \mathrm{O}_{5} \mathrm{~F}$ & $3.89-3.92$ & 376 & 376.1299 & 376.1303 & -1.0 & 10.5 \\
\hline LF377 & $\mathrm{C}_{18} \mathrm{H}_{20} \mathrm{~N}_{3} \mathrm{O}_{5} \mathrm{~F}$ & $4.39-4.46$ & 378 & 378.1447 & 378.1460 & -3.4 & 9.5 \\
\hline LF335 & $\mathrm{C}_{16} \mathrm{H}_{18} \mathrm{~N}_{3} \mathrm{O}_{4} \mathrm{~F}$ & $4.79-4.80$ & 336 & 336.1359 & 336.1354 & +1.5 & 8.5 \\
\hline LF300 & $\mathrm{C}_{15} \mathrm{H}_{9} \mathrm{~N}_{2} \mathrm{O}_{4} \mathrm{~F}$ & $8.10-8.13$ & 301 & 301.0615 & 301.0619 & -1.3 & 11.5 \\
\hline LF128 & $\mathrm{C}_{5} \mathrm{H}_{8} \mathrm{~N}_{2} \mathrm{O}_{2}$ & $2.25-2.26$ & 129 & 129.0656 & 129.0659 & -2.3 & 2.5 \\
\hline LF385 & $\mathrm{C}_{15} \mathrm{H}_{19} \mathrm{~N}_{3} \mathrm{O}_{9}$ & $2.25-2.26$ & 386 & 386.1184 & 386.1194 & -2.6 & 7.5 \\
\hline LF389 & $\mathrm{C}_{18} \mathrm{H}_{16} \mathrm{~N}_{3} \mathrm{O}_{6} \mathrm{~F}$ & $6.14-6.15$ & 390 & 390.1065 & 390.1096 & -7.9 & 11.5 \\
\hline LF391 & $\mathrm{C}_{18} \mathrm{H}_{18} \mathrm{~N}_{3} \mathrm{O}_{6} \mathrm{~F}$ & $7.08-7.10$ & 392 & 392.1270 & 392.1252 & +4.6 & 10.5 \\
\hline LF389' & $\mathrm{C}_{18} \mathrm{H}_{16} \mathrm{~N}_{3} \mathrm{O}_{6} \mathrm{~F}$ & $6.52-6.70$ & 390 & 390.1090 & 390.1096 & -1.5 & 11.5 \\
\hline LF306 & $\mathrm{C}_{15} \mathrm{H}_{15} \mathrm{~N}_{2} \mathrm{O}_{4} \mathrm{~F}$ & $5.16-5.32$ & 307 & 307.0724 & 307.1089 & -11.9 & 8.5 \\
\hline LF363 & $\mathrm{C}_{17} \mathrm{H}_{18} \mathrm{~N}_{3} \mathrm{O}_{5} \mathrm{~F}$ & $6.52-6.76$ & 364 & 364.1301 & 364.1303 & -0.5 & 9.5 \\
\hline LF363' & $\mathrm{C}_{17} \mathrm{H}_{18} \mathrm{~N}_{3} \mathrm{O}_{5} \mathrm{~F}$ & $6.77-6.97$ & 364 & 364.1293 & 364.1303 & -2.7 & 9.5 \\
\hline
\end{tabular}

a Double-bond equivalent.

chlorination of LF, but dehydrogenation was not observed in this reaction system (El Najjar et al., 2013). During the degradation of LF377(2) to LF335(1), LF359(1) might be produced by removing one $\mathrm{H}_{2} \mathrm{O}$ from the $-\mathrm{C}_{1^{\prime}}-\mathrm{C}_{2^{\prime}}$ - bond of LF377(2) (i.e., forming the $-\mathrm{C}_{1^{\prime}}=$ $\mathrm{C}_{2^{\prime}}-$ bond). As shown in Fig. S6, LF335 was vulnerable to $\mathrm{MnO}_{4}^{-}$ oxidation, whose relative abundance declined quickly after a reaction time of $5 \mathrm{~min}$; in contrast, the relative abundance of LF377 increased quickly within the first 5 min, and then kept increasing slowly until it started to decline after $20 \mathrm{~min}$.

In the chemical structure of $\mathrm{LF} 377(1)$, the $\mathrm{N}_{4}-\mathrm{CH}_{2} \mathrm{OH}$ group and the $\mathrm{N}_{1}$ atom both withdrew electrons from $-\mathrm{C}_{4^{\prime}}-\mathrm{C}_{5^{\prime}}-$ and $-C_{7^{\prime}}-C_{8^{\prime}}-$, which may lead to the simultaneous cleavage of the two bonds upon $\mathrm{MnO}_{4}^{-}$attack, and then a triple bond (i.e., $-\mathrm{C}_{4^{\prime}} \equiv \mathrm{C}_{8^{\prime}}-$ ) was formed to produce LF300. Fig. S8 shows that after reaction for 30 min, $\mathrm{NO}_{2}^{-}$and $\mathrm{NO}_{3}^{-}$occupied $1.9 \%$ and $1.5 \%$ of the total $\mathrm{N}$ in $\mathrm{LF}$, which probably arose from the removal of $\mathrm{N}_{4}$ from LF377(1). The degradation of LF375(1) could produce LF128 and LF385. The removal of $\mathrm{C}_{4^{\prime}}$ from LF375(1) (to form LF385) could induce the formation of formate. The loss of one carbon atom from LF was also observed during ozone treatment (De Witte et al., 2009). In addition, the degradation of LF375(1) to LF385 released $\mathrm{F}^{-}$, which occupied $49.2 \%$ of the total $\mathrm{F}$ in LF after reaction for $30 \mathrm{~min}$ (Fig. S8). LF389 (LF389(1) + LF389(2)) was formed through carboxylation of LF375 (LF375(1) + LF375(2)). Similarly, LF391 (LF391(1) + LF391(2)) was formed through carboxylation of LF377 (LF377(1) + LF377(2)). LF391(3) was either formed through hydroxylation of LF375(2) or both hydroxylation and dehydrogenation of LF377(2). The dehydrogenation of $-C_{1^{\prime}}-C_{2^{\prime}}-$ or $-C_{2^{\prime}}-C_{3^{\prime}}-$ of LF391(1) induced the formation of LF389' (LF389(3) + LF389(4)).

It can be concluded that the degradation of LF and its byproducts during $\mathrm{MnO}_{4}^{-}$oxidation was mainly through hydroxylation, dehydrogenation and carboxylation, which occurred at the $-\mathrm{CH}_{3}$, $-\mathrm{C}-\mathrm{C}-$ and $-\mathrm{CH}_{2} \mathrm{OH}$ groups, respectively. In comparison, for $\mathrm{LF}$ degradation by other oxidation processes, free chlorine tended to substitute the $-\mathrm{COOH}$ group with a chlorine atom, and ozone tended to add an $\mathrm{O}$ atom to the $\mathrm{N}_{4}$ (De Witte et al., 2009; El Najjar et al., 2013). As shown in Fig. S8, TOC was only removed by $5.4 \%$ after reaction for $30 \mathrm{~min}$, which agrees with the low removal of 
a<smiles>CC1COc2c(N(C)C)c(F)cc3c(=O)c(C(=O)O)cn1c23</smiles>

LF306<smiles>O=C1C2=CC(C(=O)O)CC=C2C(N2CCN(CO)CC2)=CC1F</smiles>

LF363<smiles>CCN1C=C(C(=O)O)C(=O)C2C=C(F)C(N3CCN(C=O)CC3)C(O)=C21</smiles>

LF363'

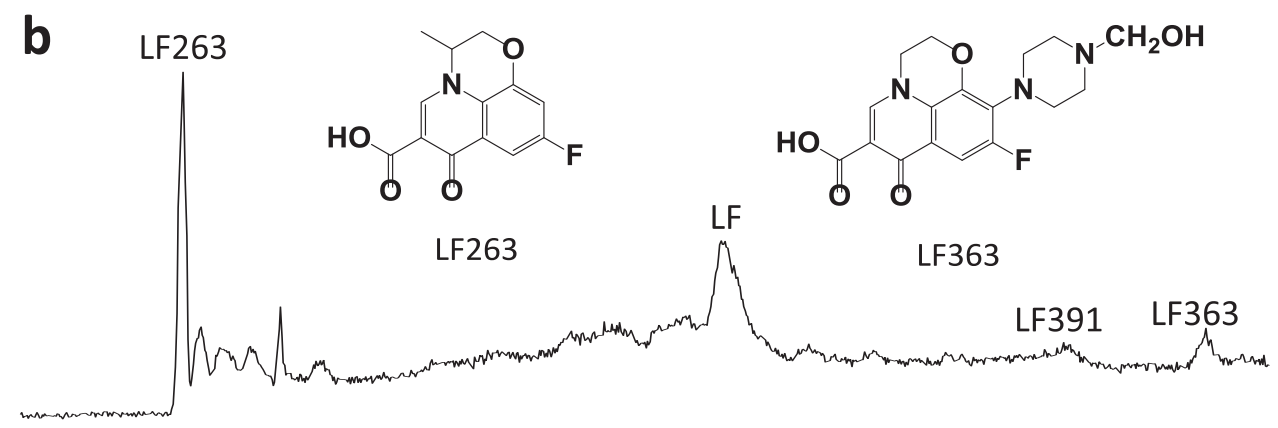

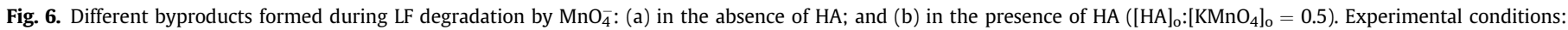
reaction time $=45-125 \mathrm{~min}$, with others being the same as in Fig. 5 .

carbon from LF and its byproducts.

Fig. 6 compares the degradation byproducts of LF in the absence and presence of HA during the reaction period of 45-125 min. In the absence of HA, LF389, LF389' and LF391 could still be detected but with much lower intensities than those within the first $30 \mathrm{~min}$, and three new byproducts including LF306, LF363 and LF363 were identified (Fig. 6a and S9). In the presence of HA $\left([\mathrm{HA}]_{\mathrm{o}}:\left[\mathrm{KMnO}_{4}\right]_{\mathrm{o}}=0.5\right), \mathrm{LF} 363$ and LF391 were also detected, but a new byproduct (LF263, Fig. S9) emerged with a high peak (Fig. 6b). LF263 has the simplest structure among the high-molecular-weight organic byproducts formed during LF degradation by $\mathrm{MnO}_{4}^{-}$, which denotes a stronger destruction of LF in the presence of HA (i.e., additional oxidation by [HA-Mn(III)] and $\bullet \mathrm{OH}$ ).

\section{Conclusions}

This study investigated the impact of HA on LF degradation by $\mathrm{MnO}_{4}^{-}$in water from both kinetic and mechanistic aspects. Based on the experimental results obtained, the following conclusions can be drawn:

- In the absence of $\mathrm{HA}, \mathrm{LF}$ reacted toward $\mathrm{MnO}_{4}^{-}$with a secondorder rate constant $(k)$ of $3.9 \mathrm{M}^{-1} \mathrm{~s}^{-1}$ at $\mathrm{pH}$ 7.5. As the $\mathrm{pH}$ decreased from 8.5 to 6.5 , the protonation of the $\mathrm{N}_{4}$ atom facilitated the degradation of LF by enhancing the electrophilicity of structural groups adjacent to $\mathrm{N}_{4}$.

- At $[\mathrm{HA}]_{0}:\left[\mathrm{KMnO}_{4}\right]_{\mathrm{o}}$ (mass ratio) $=0.5$ and 1, the pseudo-firstorder rate constant $\left(k_{\text {obs }}\right)$ of LF degradation was significantly increased by 3.8 - and 2.8 -fold at $\mathrm{pH} 7.5$, respectively. Secondary oxidant scavenging tests indicated that oxygen-centered radicals could be produced in the reaction of $\mathrm{MnO}_{4}^{-}$with $\mathrm{HA}$.

- HA could form a complex with $\mathrm{Mn}$ (III) to successively produce $\mathrm{O}_{2} \cdot{ }^{-}$and $\bullet \mathrm{OH}$. The $\bullet \mathrm{OH}$ primarily contributed to the accelerated LF degradation, and the complex [HA-Mn(III)] could account for the rest of acceleration.

- The degradation of LF and its byproducts during $\mathrm{MnO}_{4}^{-}$oxidation was mainly through hydroxylation, dehydrogenation and carboxylation reactions occurring at the $-\mathrm{CH}_{3},-\mathrm{C}-\mathrm{C}-$ and
$-\mathrm{CH}_{2} \mathrm{OH}$ groups, respectively. The presence of HA caused a stronger destruction of LF.

\section{Acknowledgements}

This study was supported by the National Natural Science Foundation of China $(51290281,51525806,21590814)$ and the Chinese Academy of Sciences (QYZDY-SSW-DQC004).

\section{Appendix A. Supplementary data}

Supplementary data related to this article can be found at http:// dx.doi.org/10.1016/j.watres.2017.06.037.

\section{References}

Cavalcante, R.P., Dantas, R.F., Bayarri, B., González, O., Giménez, J., Esplugas, S., Junior, A.M., 2016. Photocatalytic mechanism of metoprolol oxidation by photocatalysts $\mathrm{TiO}_{2}$ and $\mathrm{TiO}_{2}$ doped with $5 \% \mathrm{~B}$ : primary active species and intermediates. Appl. Catal. B 194, 111-122.

Conley, J.M., Symes, S.J., Schorr, M.S., Richards, S.M., 2008. Spatial and temporal analysis of pharmaceutical concentrations in the upper Tennessee River basin. Chemosphere 73 (8), 1178-1187.

De Witte, B., Van Langenhove, H., Hemelsoet, K., Demeestere, K., De Wispelaere, P., Van Speybroeck, V., Dewulf, J., 2009. Levofloxacin ozonation in water: rate determining process parameters and reaction pathway elucidation. Chemosphere 76 (5), 683-689.

Du, J.S., Sun, B., Zhang, J., Guan, X.H., 2012. Parabola-like shaped pH-rate profile for phenols oxidation by aqueous permanganate. Environ. Sci. Technol. 46 (16), 8860-8867.

El Najjar, N.H., Deborde, M., Journel, R., Vel Leitner, N.K., 2013. Aqueous chlorination of levofloxacin: kinetic and mechanistic study, transformation product identification and toxicity. Water Res. 47 (1), 121-129.

Finkelstein, E., Rosen, G.M., Rauckman, E.J., 1980. Spin trapping of superoxide and hydroxyl radical: practical aspects. Arch. Biochem. Biophys. 200 (1), 1-16.

Gao, S.S., Zhao, Z.W., Xu, Y.P., Tian, J.Y., Qi, H., Lin, W., Cui, F.Y., 2014. Oxidation of sulfamethoxazole (SMX) by chlorine, ozone and permanganate - a comparative study. J. Hazard. Mater. 274, 258-269.

Goodwin, S.D., Gallis, H.A., Chow, A.T., Wong, F.A., Flor, S.C., Bartlett, J.A., 1994. Pharmacokinetics and safety of levofloxacin in patients with human immunodeficiency virus infection. Antimicrob. Agents Chemother. 38 (4), 799-804.

He, D., Guan, X.H., Ma, J., Yu, M., 2009. Influence of different nominal molecular weight fractions of humic acids on phenol oxidation by permanganate. Environ. Sci. Technol. 43 (21), 8332-8337.

Henry, T.D., Archer, S.L., Nelson, D., Weir, E.K., From, A.H.L., 1990. Enhanced chemiluminescence as a measure of oxygen-derived free radical generation during 
ischemia and reperfusion. Circ. Res. 67 (6), 1453-1461.

Hu, L.H., Martin, H.M., Arce-Bulted, O., Sugihara, M.N., Keating, K.A., Strathmann, T.J., 2009. Oxidation of carbamazepine by $\mathrm{Mn}(\mathrm{VII})$ and $\mathrm{Fe}(\mathrm{VI})$ : reaction kinetics and mechanism. Environ. Sci. Technol. 43 (2), 509-515.

Hu, L.H., Martin, H.M., Strathmann, T.J., 2010. Oxidation kinetics of antibiotics during water treatment with potassium permanganate. Environ. Sci. Technol. 44 (16), 6416-6422.

Jiang, J., Pang, S.Y., Ma, J., 2009. Oxidation of triclosan by permanganate (Mn(VII)): importance of ligands and in situ formed manganese oxides. Environ. Sci. Technol. 43 (21), 8326-8331.

Jiang, J., Pang, S.Y., Ma, J., 2010. Role of ligands in permanganate oxidation of organics. Environ. Sci. Technol. 44 (11), 4270-4275.

Jiang, J., Pang, S.Y., Ma, J., Liu, H.L., 2012. Oxidation of phenolic endocrine disrupting chemicals by potassium permanganate in synthetic and real waters. Environ. Sci. Technol. 46 (3), 1774-1781.

Kim, J.W., Jang, H.S., Kim, J.G. Ishibashi, H., Hirano, M., Nasu, K., Ichikawa, N. Takao, Y., Shinohara, R., Arizono, K., 2009. Occurrence of pharmaceutical and personal care products (PPCPs) in surface water from Mankyung River, South Korea. J. Health Sci. 55 (2), 249-258.

Lawrence, A., Jones, C.M., Wardman, P., Burkitt, M.J., 2003. Evidence for the role of a peroxidase compound I-type intermediate in the oxidation of glutathione, $\mathrm{NADH}$, ascorbate, and dichlorofluorescin by cytochrome $\mathrm{c} / \mathrm{H}_{2} \mathrm{O}_{2}$. Implications for oxidative stress during apoptosis. J. Biol. Chem. 278 (32), 29410-29419.

Marino, D.F., Ingle, J.D., 1981. Determination of humic acid by chemiluminescence Anal. Chim. Acta 124 (1), 23-30.

Mittmann, N., Jivraj, F., Wong, A., Yoon, A., 2002. Oral fluoroquinones in the treatment of pneumonia, bronchitis and sinusitis. Can. J. Infect. Dis. 13 (5), 293-300.

Rodríguez-Álvarez, T., Rodil, R., Quintana, J.B., Cela, R., 2015. Reactivity of $\beta$-blockers/ agonists with aqueous permanganate. Kinetics and transformation products of salbutamol. Water Res. 79, 48-56.

Sharma, V.K. Triantis, T.M., Antoniou, M.G. He, X.X. Pelaez, M., Han, C.S., Song, W.H., O'Shea, K.E., De la Cruz, A.A., Kaloudis, T., Hiskia, A., Dionysiou, D.D.,
2012. Destruction of microcystins by conventional and advanced oxidation processes: a review. Sep. Purif. Technol. 91, 3-17.

Sławiński, J., 1988. Luminescence research and its relation to ultraweak cell radiation. Experientia 44 (7), 559-571

Sun, B., Guan, X.H., Fang, J.Y., Tratnyek, P.G., 2015. Activation of manganese oxidants with bisulfite for enhanced oxidation of organic contaminants: the involvement of Mn(III). Environ. Sci. Technol. 49 (20), 12414-12421.

Sun, B., Zhang, J., Du, J.S., Qiao, J.L., Guan, X.H., 2013. Reinvestigation of the role of humic acid in the oxidation of phenols by permanganate. Environ. Sci. Technol. 47 (24), 14332-14340.

Tsai, P., Ichikawa, K., Mailer, C., Pou, S., Halpern, H.J., Robinson, B.H., Nielsen, R. Rosen, G.M., 2003. Esters of 5-carboxyl-5-methyl-1-pyrroline $N$-oxide: a family of spin traps for superoxide. J. Org. Chem. 68 (20), 7811-7817.

Waldemer, R.H., Tratnyek, P.G., 2006. Kinetics of contaminant degradation by permanganate. Environ. Sci. Technol. 40 (3), 1055-1061.

Wong, F.A., Juzwin, S.J., Flor, S.C., 1997. Rapid stereospecific high-performance liquid chromatographic determination of levofloxacin in human plasma and urine. J. Pharm. Biomed. Anal. 15 (6), 765-771.

Yuan, X.J., Qiang, Z.M., Ben, W.W., Zhu, B., Qu, J.H., 2015. Distribution, mass load and environmental impact of multiple-class pharmaceuticals in conventional and upgraded municipal wastewater treatment plants in East China. Environ. Sci. Process. Impacts 17 (3), 596-605.

Zhang, H., Joseph, J., Vasquez-Vivar, J., Karoui, H., Nsanzumuhire, C., Martásek, P. Tordo, P., Kalyanaraman, B., 2000. Detection of superoxide anion using an isotopically labeled nitrone spin trap: potential biological applications. FEBS Lett. 473 (1), 58-62.

Zhang, J., Sun, B., Huang, Y.Y., Guan, X.H., 2015. Catalyzing the oxidation of sulfamethoxazole by permanganate using molecular sieves supported ruthenium nanoparticles. Chemosphere 141, 154-161.

Zhou, Y., Jiang, J., Gao, Y., Ma, J., Pang, S.Y., Li, J., Lu, X.T., Yuan, L.P., 2015. Activation of peroxymonosulfate by benzoquinone: a novel nonradical oxidation process. Environ. Sci. Technol. 49 (21), 12941-12950. 